\title{
Pendistribusian Kartu Indonesia Pintar (KIP)
}

\author{
Ratna Indah Cahyaningsih \\ Universitas Kristen Satya Wacana, Salatiga \\ Email: 292015093@student.uksw.edu
}

\begin{abstract}
The Indonesia Pintar Program (PIP) is an enhanced support program for the government for Poor Student Assistance (BSM). The PIP program is expected to help students who are economically disadvantaged and can ease the burden of disadvantaged families, and withdraw students who drop out of school due to delinquent fees. So it is hoped that there will be no more reason not to continue their education to a higher level because of cost problems. For the use of funds to be used as effectively and efficiently as possible. Thus the PIP program can support the government's 12-year compulsory education program. Both programs can go hand in hand with the Indonesian national goal of Educating Nation's Life.
\end{abstract}

Keywords: Indonesia Pintar Card, Distribution, Students

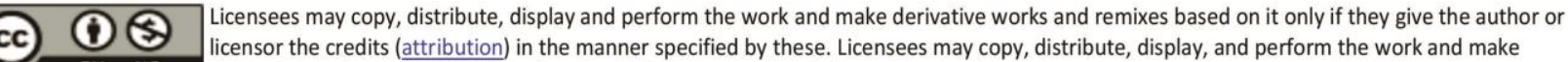
derivative works and remixes based on it only for non-commercial purposes.

\section{PENDAHULUAN}

Program Indonesia Pintar (PIP) yaitu suatu program yang menjadi prioritas oleh Presiden Republik Indonesia Ir. Joko Widodo yang dirancang khusus untuk membantu anak yang berasal dari keluarga miskin dan kurang mampu. Agar pendidikannya dapat dijamin dari Sekolah Dasar (SD), Sekolah Menengah Pertama (SMP), dan Sekolah Menengah Atas (SMA) atau Sekolah Menengah Kejuruan (SMK) sederajat (Retnaningsih, 2017).

Untuk program Indonesia Pintar ini, Presiden Joko Widodo bekerja sama dengan Kementerian Agama (Kemenag), Kementerian Pendidikan dan Kebudayaan (Kemendikbud) dan juga Kementerian Sosial (Kemensos). Hal ini dilakukan untuk untuk membantu dan mempermudah jalannya program Indonesia Pintar. Selain itu, program Indonesia Pintar ini, digunakan membantu masyarakat yang kurang mampu untuk membiayai anak mereka, menekan atau mencegah siswa putus sekolah dan dapat membantu siswa yang putus sekolah untuk melanjutkan satuan pendidikan formal maupun informal, yang sebagian berasal dari keluarga penerima kartu Program Keluarga Harapan (PKH) dan kartu Perlindungan Sosial (KPS) (Saraswati, 2017).

Dalam penerapan program Indonesia Pintar, Indonesia sehat dan Indonesia sejahtera memiliki payung hukum yang dapat dipertanggungjawabkan, pelaksanaannya mulai dari Pasal 34 Ayat (1) dan (3) UUD 1945, UU Nomor 25/2004 tentang Sistem Perencanaan Pembangunan Nasional yang menyebutkan bahwa janji-janji presiden saat kampanye pemilihan presiden wajib dilaksanaakan sesuai dengan ketentuan peraturan perundangundangan yang berlaku, mengatur kewajiban negara memberikan sistem jaminan sosial bagi seluruh rakyat serta Instruksi presiden Nomor 7 Tahun 2014 tentang pelaksanaan Program Simpanan Keluarga Sejahtera, Program Indonesia Sehat untuk membangun keluarga produktif, mengamanatkan agar Kartu Indonesia Pintar diberikan kepada anak-anak 
yang berusia 6 sampai 21 tahun dari keluarga pemegang Kartu Keluarga Sejahtera (KKS) sebagai identitas untuk mendapatkan manfaat program Indonesia Pintar.

Kartu Indonesia Pintar (KIP) harus tepat sasaran agar dapat digunakan dengan sebaik mungkin, di daerah diharapkan agar pemerintahan yang menangani pembagian KIP ini, diseleksi sebaik mungkin untuk menghindari salah sasaran. Karena di setiap daerah di Indonesia banyak masyarakat yang sangat membutuhkan bantuan dari pemerintah, mereka yang sangat membutuhkan dana dan biaya untuk membantu meringankan perekonomian keluarga (Nurmiati, 2017).

Masyarakat Indonesia diharapkan agar menggunakan Kartu Indonesia Pintar dengan sebaik mungkin, guna membantu program pemerintah yaitu menekan angka putus sekolah yang dilatarbelakangi oleh biaya. Jadi, masyarakat harus sejalan dengan program pemerintah ini. Sebagai orang tua agar lebih bijak dalam membelikan perlengkapan sekolah anak, dengan demikian biaya yang dikeluarkan dapat seefektif mungkin, membeli seperlunya saja.

Program Indonesia Pintar (PIP) melalui Kartu Indonesia Pintar (KIP) adalah salah satu program nasional (tercantum dalam Rencana Pembangunan Jangka Menengah Nasional 2015 sampai 2019) yang bertujuan untuk (Astuti, 2017):

1) Meningkatkan angka partisipasi pendidikan dasar dan menengah

2) Meningkatkan angka keberlanjutan pendidikan yang ditandai dengan menurunnya angka putus sekolah dan angka melanjutkan.

3) Menurunnya kesenjangan pendidikan antar kelompok masyarakat, terutama antara penduduk kaya dan penduduk kurang mampu, antara penduduk laki-laki dan perempuan, antara wilayah perkotaan dan wilayah perdesaan dan antar daerah.

4) Meningkatkan kesiapan siswa pendidikan menengah memasuki pasar kerja atau melanjutkan ke jenjang pendidikan tinggi.

Kartu Indonesia Pintar ini diberikan ke seluruh provinsi di Indonesia, sesuai dari penyedia jasa pengiriman Kartu Indonesia Pintar. Setiap daerah, masyarakat didata dan diseleksi guna mendapatkan masyarakat yang benar-benar membutuhkannya. Kebijakan ini diharapkan dapat membantu perekonomian masyarakat guna membiayai pendidikan anaknya dan menekan angkan putus sekolah yang dari tahun ke tahun semakin meningkat.

Berdasarkan latar belakang di atas, dapat dikatakan bahwa program pemerintah belum bisa membantu masyarakat semaksimal mungkin. Melihat belum meratanya kartu Indonesia Pintar, di beberapa daerah Kartu Indonesia Pintar ini terkendala, contohnya di Medan, dikutip dari koran Sinar Indonesia Baru (SIB), pendistribusian Kartu Indonesia Pintar dinilai tidak tepat sasaran. Para penerima KIP sudah tidak bersekolah dan sudah menikah, menurut masyarakat pendataannya asal-asalan, banyak masyarakat yang sangat membutuhkan bantuan KIP itu, namun namanya tidak terdaftar dalam penerima KIP tersebut. Pemerintah diharapkan dapat sebijak mungkin dalam mendata siswa yang benar-benar membutuhkan, dan tepat sasaran, sebaiknya sebelum pendataan berlangsung diadakan sosialisasi agar masyarakat paham akan bantuan KIP tersebut.

\section{HASIL PENELITIAN DAN PEMBAHASAN}

\section{Pendistribusian Kartu Indonesia Pintar}

Dalam penerapan Program Indonesia Pintar memiliki payung hukum yang dapat dipertanggungjawabkan pelaksanaannya mulai dari Pasal 34 Ayat 1 dan 3 UUD 1945, UU Nomor 25/2004 tentang Sistem Perencanaan Pembangunan Nasional yang menyebutkan bahwa janji-janji presiden saat kampanye pemilihan presiden wajib dilaksanakan sesuai dengan ketentuan peraturan perundangundangan yang berlaku yang mengatur kewajiban negara memberikan sistem jaminan sosial bagi seluruh rakyat serta Instruksi Presiden Nomor 7 Tahun 2014 tentang Pelaksanaan Program Simpanan Keluarga Sejahtera, Program Indonesia Pintar, dan Program Indonesia Sehat. Program Indonesia Pintar melalui Kartu Indonesia Pintar adalah salah satu program nasional (tercantum dalam Rencana Pembangunan Jangka Menengah Nasional 2015 - 2019).

Dirjen Pendidikan Dasar dan Menengah Kementrian Pendidikan dan Kebudayaan (Kemendikbud) mengatakan 
banyak siswa di beberapa daerah di Tanah Air belum menerima Kartu Indonesia Pintar (KIP) karena masalah administrasi. Dari 17,9 juta penerima KIP yang ditargetkan pada 2016 telah mampu diditribusikan sebanyak 17,4 juta kartu. Namun, permasalahannya adalah dari jumlah 17,4 juta tersebut, sekitar 10 hingga 20 persen siswa belum menerima KIP. Permasalahannya penyedia layanan pengiriman KIP tidak dikirimkan ke alamat penerima KIP di seluruh Indonesia, semua kartu hanya dikirim ke kantor camat dan kelurahan sehingga menambah pekerjaan pemerintah setempat untuk menyalurkannya (Suastha, 2016).

Berdasarkan kejadian tersebut, keterangan aparat desa penyedia pengiriman hanya mengirimkan KIP ke kantor kecamatan dan desa, tidak langsung ke alamat penerima KIP, bermasalah di setiap daerah, ribuan KIP menumpuk di kantor kelurahan dan banyak penerima KIP tidak tepat sasaran dari 17 juta KIP yang dicetak pada 2015, hanya sebesar 40 $\%$ yang terserap. Untuk menghindari kejadian tersebut pemerintah mengganti mekanisme pendistribusian KIP tersebut, jadi pendistribusian KIP tersebut akan disalurkan ke sekolah sesuai data pokok pendidikan.

\section{Kebijakan Publik}

Menurut

Suharto

dalam

Taufiqurokhman (2014) hakikat kebijakan publik sebagai jenis tindakan yang mengarahkan pada tujuan yang terdiri dari beberapa kategori sebagai berikut:

1. Tuntutan Kebijakan (policy demand) adalah tuntutan atau desakan yang ditujukan pada pejabat-pejabat pemerintah yang dilakukan oleh actor-aktor lain baik swasta ataupun kalangan dalam pemerintah sendiri, dalam sistem politik untuk melakukan tindakan tertentu atau sebaliknya tidak berbuat sesuatu terhadap tindakan tersebut.

2. Keputusan Kebijakan (policy decions) adalah keputusan yang dibuat oleh para pejabat pemerintah untuk memberikan keabsahan (legitimasi), wewenang atau memberikan arah terhadap pelaksanaan kebijakan publik.
3. Pernyataan Kebijakan (policy statements) adalah pernyataan resmi atau penjelasan mengenai kebijakan publik tertentu.

4. Keluaran Kebijakan (policy outputs) adalah wujud kebijakan publik yang paling kongkret artinya dapat dirasakan oleh masyarakat karena menyangkut hal-hal yang dilakukan guna merealisasikan apa yang telah digarasikan dalam keputusan dan pernyataan kebijakan.

5. Hasil Akhir Kebijakan (policy outcomes) adalah akibat atau dampak langsung yang benar dirasakan oleh masyarakat baik yang diharapkan ataupun yang tidak diharapkan sebagai konsekuensinya dari adanya tindakan atau tidak adanya tindakan pemerintah dalam bidang atau masalah tertentu yang ada di masyarakat.

Kesimpulannya kebijakan politik tidak hanya mengatur segala aspek dalam tatanan negara dan tidak hanya mengatur pejabat publik tetapi mengatur juga tatanan masyarakat. Implementasi kebijakan merupakan suatu proses, serangkaian keputusan dan tindakan yang bertujuan untuk melaksanakan keputusan pemerintah atau keputusan legislasi negara yang telah dibuat atau dirumuskan sebelumnya. Proses implementasi kebijakan tidak hanya menyangkut perilaku badan-badan administratif yang bertanggung jawab untuk melaksanakan program dan menimbulkan ketaatan pada diri kelompok sasaran.

Namun juga menyangkut kepada jaringan-jaringan politik, ekonomi dan sosial yang secara langsung atau tidak langsung dapat memengaruhi perilaku dari semua pihak yang terlibat dengan beragam aturan spesifik, situasi yang serba ideal dari segi perundangannya yang sudah jelas, unit-unit organisasi berikut staf yang diberi tugas dan sudah terlatih dengan baik, biaya yang diperlukan sudah tersedia tentunya diperlukan penyesuaianpenyesuaian.

\section{Program Indonesia Pintar}

Program Indonesia Pintar (PIP) melalui Kartu Indonesia Pintar (KIP) adalah pemberian bantuan tunai pendidikan kepada anak usia sekolah dari umur 6 tahun sampai dengan 21 tahun yang berasal dari keluarga miskin, rentan miskin yaitu pemilik Kartu Keluarga Sejahtera 
dan Program Keluarga Harapan (PKH) yatim piatu, penyandang disabilitas, korban bencana alam dan musibah. PIP merupakan bagian dari penyempurnaan Program Bantuan Siswa Miskin (BSM). Sasaran utama dari program PIP ini adalah peserta penerima Kartu Indonesia Pintar, peserta didik dari keluarga miskin atau rentan miskin dengan pertimbangan khusus seperti yatim piatu, penyandang disabilitas, korban bencana alam dan musibah dan peserta didik SMK yang menempuh studi keahlian kelompok bidang pertanian, perikanan, kehutanan, pelayaran dan kemaritiman.

Untuk penggunaan KIP, penerima harus terdaftar sebagai peserta didik di lembaga pendidikan formal seperti SD, SMP, SMA/SMK atau pendidikan non formal seperti Pusat Kegiatan Belajar Masyarakat (PKBM) Surat Keterangan Bebas (SKB) dan Lembaga Khusus Pelatihan (LKP) dan peserta KIP harus terdaftar di data pokok pendidikan (Dapodik) lembaga pendidikan.

Program KIP ini ditujukan untuk menghilangkan hambatan ekonomi siswa untuk bersekolah, tidak dapat dipungkiri bahwa penduduk di Indonesia masih banyak yang berpenghasilan di bawah rata-rata, pekerjaan tidak tetap, dan kurangnya lapangan pekerjaan hal tersebut sangat memengaruhi pendapatan penduduk, sehingga anak-anaklah yang menjadi korban untuk berhenti sekolah, karena kondisi ekonomi keluarga. Dengan banyaknya anak yang berhenti sekolah akan menjadikan angka putus sekolah semakin meningkat dari tahun ke tahun. Faktor yang memengaruhinya adalah biaya pendidikan yang tinggi, maka Program Indonesia Pintar ini, melalui Kartu Indonesia Pintar membantu anak agar tidak mempunyai pikiran untuk berhenti sekolah karena masalah biaya. Selain untuk menghindari anak putus sekolah, program ini juga ditujukan untuk merekrut atau menarik kembali siswa yang pernah putus sekolah agar dapat mengenyam pendidikan seperti sebelumnya (Djoyosuroto, Prasetyono, \& Mulyani, 2018).

Banyaknya anak di bawah umur yang putus sekolah dan bekerja di bawah umur, program ini tidak hanya membantu untuk memenuhi biaya pendidikan anak, namun juga membantu anak dalam memenuhi kebutuhan pemebelajarannya, seperti seragam, sepatu, tas, alat tulis dan lainnya. Program Indonesia Pintar ini juga mendukung program pemerintah Wajib Belajar 12 Tahun. Karena KIP berlaku hingga siswa berumur 21 Tahun, maka siswa dapat lebih terbantu dengan adanya KIP tersebut. KIP juga mencangkup anak usia sekolah yang tidak berada di sekolah seperti Penyandang Masalah Kesejahteraan Sosial (PMKS) seperti anak di panti asuhan/sosial, anak jalanan, dan pekerja anak dan difabel.

Jadi untuk siswa yang berada di panti asuhan bisa mendapatkan KIP, anak jalanan yang putus sekolah akan terjamin pendidikannya, dan untuk difabel yang mempunyai kebutuhan khusus dapat terbantu. Dengan adanya KIP dan siswa penyandang difabel dapat tersalurkan ke dalam keahlian dan kebutuhan sesuai keistimewaan yang dimiliki. KIP juga berlaku di pondok pesantren, pusat kegiatan belajar masyarakat dan lembaga kursus dan pelatihan yang ditentukan oleh pemerintah.

KIP menarik siswa yang tidak terdaftar di satuan lembaga pendidikan untuk kembali bersekolah dan KIP menjamin keberlanjutan bantuan antar jenjang pendidikan sampai tingkat SMA/SMK dan sederajat. Jadi program pemerintah Wajib Belajar 12 Tahun akan berjalan dengan baik, dengan adanya bantuan dari Kartu Indonesia Pintar. Maka siswa di seluruh Indonesia akan terjamin pendidikannya sampai jenjang yang tinggi.

Untuk KIP di setiap daerah harus pintar untuk menyeleksi siswa yang benar-benar membutuhkan agar tepat sasaran. Untuk pendataan penerimaan KIP ini, siswa diseleksi menurut data sekolah, hal ini dapat memungkinkan kurang efektif karena siswa data di sekolah bisa saja sudah lama, seperti di Medan dengan menggunakan data dari sekolah, pemerintah mengambil data yang sudah lama, sehingga siswa yang mendapat KIP adalah siswa yang sudah lulus dan sudah menikah, siswa yang benar-benar membutuhkan namanya tidak tercantum. Seharusnya untuk pendataan pemerintah dapat mengambil data yang terbaru, agar siswa yang benar-benar membutuhkan dapat terbantu dengan baik. Jika tidak sekolah dapat 
mengirim rekapitulasi siswa yang kurang mampu di setiap sekolahnya agar tepat sasaran.

Alangkah baiknya jika pendataan penerima KIP dapat dilakukan oleh perangkat desa, di mana perangkat desa lebih mengerti masyarakat yang membutuhkan. Perangkat desa bekerja sama dengan sekolah untuk survei keadaan dan kondisis siswa penerima KIP, agar tidak salah sasaran. KIP ini merupakan penyempurnaan dari BSM (Bantuan Siswa Miskin), KIP ini merupakan program yang intinya dapat membantu siswa untuk tidak putus sekolah dan menarik kembali siswa yang sudah putus sekolah karena biaya. Jadi melalui KIP ini tidak ada alasan lagi tentang putus sekolah yang dilatarbelakangi oleh biaya karena untuk biaya administrasi sekolah sudah ditanggung BOS (Biaya Operasional Sekolah) dan untuk biaya perlengkapan sekolah sudah dibantu KIP.

Untuk besaran dana KIP setiap jenjang pendidikan berbeda, SD/MI/Diniyah formal ula/SDTK, pondok pesantren dan kejar paket A/PPS wajar pendidikan dasar sebesar Rp. 400.000, untuk SMP/MTs/Diniyah formal wustha/SMPTK, podok pesantren, kejar paket B/PPS wajar dikdas wustha sebesar Rp. 500.000, dan untuk SMA/SMK/MA/diniyah formal ulya/muadalah/SMTK/SMAK. Pondok pesantren, dan kejar paket C/PMU ulya/ Lembaga Pelatihan/kursus sebesar Rp. 700.000 .

\section{Tujuan Program Indonesia Pintar}

1. Meningkatkan peluang bagi anak usia 6 tahun sampai 21 tahun untuk mendapatkan peluang menempuh pendidikan dari Sekolah Dasar (SD) sampai dengan Sekolah Menengah Atas (SMA) atau Sekolah Menengah Kejuruan (SMK) Sederajat dan untuk mendukung program wajib belajar 12 tahun yang telah ditetapkan oleh pemerintah.

2. Mencegah terjadinya siswa putus sekolah dan tidak melanjutkan ke jenjang lebih tinggi dikarenakan masalah biaya dan ekonomi.

3. Menarik kembali siswa yang putus sekolah karena masalah biaya dan siswa yang tidak melanjutkan sekolah agar mendapatkan pendidikan dengan semestinya.
4. Mendapatkan layanan pendidikan di sekolah atau Sanggar Kegiatan Belajar (SKB) atau Pusat Kegiatan Belajar Masyarakat (PKBM) atau Lembaga Khusus Pelatihan (LKP) atau Satuan Pendidikan Nonformal lainnya dan Balai Latihan Kerja (BLK).

Dari tujuan diatas pemerintah sangat menjamin generasi bangsa untuk mendapatkan pendidikan sampai ke tingkat SMA, tidak hanya pendidikan yang diterima oleh para siswa namun balai pelatihan dan sanggar juga mendukung proses dari pendidikan. Jadi siswa mendapatkan pengetahuan juga keterampilan. Pemerintah juga telah menyediakan bagi siswa yang istimewa dengan pendidikan inklusi di sekolah luar biasa, dan siswa yang mengenyam pendidikan di pondok pesantren mendapatkan bantuan sesuai kebutuhannya. Jadi, Program Indonesia Pintar ini sangat menyeluruh tidak hanya fokus pada sekolah formal, namun pada pendidikan nonformal juga mendapat bantuan. Pemerintah berharap dari PIP ini dapat membantu siswa dan bermanfaat untuk siswa yang membutuhkan.

\section{Prinsip Pelaksanaan Program Indonesia Pintar}

1. Efisien yaitu menggunakan dana dan daya yang ada untuk mencapai sasaran yang ditetapkan dengan waktu yang telah ditetapkan dan dapat dipertanggungjawabkan.

2. Efektif yaitu harus sesuai dengan kebutuhan dan dapat memberi manfaat kepada yang membutuhkan.

3. Transparan yaitu menjamin keterbukan dalam masyarakat yang dapat mengetahui dan mendapatkan informasi mengenai PIP.

4. Akuntabel yaitu pelaksanaan dapat dipertanggungjawabkan.

5. Kepatutan yaitu penjabaran kegiatan harus dilaksanakan secara realistis dan proporsional.

6. Manfaat yaitu pelaksanaan program atau kegiatan harus sesuai dengan prioritas utama nasional.

Jadi, prinsip dalam PIP saling berhubungan satu dengan yang lainnya, jika satu unsur tidak berjalan dengan baik maka akan memengaruhi unsur yang lain dengan begitu PIP tidak akan berjalan sesuai dengan 
harapan pemerintah. Maka diharapkan dari berbagai kalangan untuk mendukung penuh pelaksanaan PIP ini, agar masyarakat yang sangat membutuhkan dapat terbantu dengan adanya program ini.

\section{Sasaran Program Indonesia Pintar}

Berdasarkan Permendikbud No. 12 Tahun 2015, sasaran PIP adalah anak berusia 6 tahun sampai 21 tahun dengan kriteria sebagai berikut:

1. Siswa atau anak dari keluarga pemegang Kartu Perlindungan Sosial (KPS)/Kartu Keluarga Sejahtera (KKS).

2. Siswa atau anak dari keuarga Program Keluarga Harapan (PKH).

3. Siswa atau anak yang berstatus yatim/piatu atau yatim piatu dari pantai sosial/pantai asuhan.

4. Siswa yang tidak bersekolah (drop out) yang diharapkan kembali bersekolah.

5. Siswa yang putus sekolah akibat biaya.

6. Siswa yang terkena dampak ekonomi akibat bencana alam

7. Siswa dari keluarga miskin atau renta miskin yang terancam putus sekolah.

\section{Prosedur untuk Mendapatkan Kartu Indonesia Pintar}

Kartu Indonesia Pintar merupakan program penyempurna Bantuan Siswa Miskin (BSM), melalui KIP ini siswa dari keluarga kurang mampu dapat menerima bantuan tunai dari pemerintah secara reguler. Untuk tahap awal Kartu Indonesia Pintar diberikan bersamaan dengan pemberian Kartu Keluarga Sejahtera (KKS) dan Kartu Indonesia Sehat (KIS).

Penerima Kartu Indonesia Pintar (KIP) adalah anak usia sekolah dari pemegang Kartu Perlindungan Sosial (KPS) atau Kartu Keluarga Sejahtera (KKS). Siswa jenjang SD/MI, SMP/MTs, SMA/SMK/MA adalah siswa yang mendapat Kartu Indonesia Pintar (KIP). Untuk penerima KIP belum merata ke semua pemegang KKS karena penerima KIP dilakukan secara bertahap. Untuk menerima KIP, pemegang KKS harus membawa kartunya dan dilengkapi dengan Kartu Keluarga atau surat keterangan dari RT/RW/Lurah/Kepala Desa yang menyatakan bahwa siswa tersebut dari keluarga penerima KKS dan selanjutnya dibawa ke sekolah atau madrasah tempat anak tersebut terdaftar.

Selanjutnya, pihak sekolah memproses berkas tersebut untuk dicatat ke dalam daftar calon penerima Kartu Indonesia Pintar, lalu menyerahkan ke Dinas Pendidikan/Kantor Kementrian Agama Kabupaten/Kota yang selanjutnya mengirimkan rekapitulasi calon penerima KIP ke Kementerian Pendidikan dan Kebudayaan/Kementrian Agama. Untuk sekolah di bawah naungan Kemendikbud, operator sekolah wajib memasukkan informasi siswa dalam sistem Data Pokok Pendidikan (Dapodik). Setelah menerima rekapitulasi dari calon penerima Kartu Ondonesia Pintar (KIP), Kemendikbud/Kemenag akan mencetak dan mengirimkan Kartu Indonesia Pintar ke alamat sekolah. Untuk keluarga pemegang Kartu Perlindungan Sosial (KPS) yang telah menjadi penerima BSM, masih dapat menggunakan Kartu tersebut untuk didaftarkan menjadi penerima KIP, caranya dengan KPS dibawa ke sekolah atau madrasah untuk didaftarkan sebagai penerima KIP.

\section{Cara Menggunakan Kartu Indonesia Pintar}

Pertama, calon penerima Program Indonesia Pintar (PIP) membawa dan menunjukkan Kartu Indonesia Pintar (KIP) dengan membawa Kartu Keluarga ke sekolah/madrasah/satuan pendidikan formal maupun nonformal, di mana siswa tersebut terdaftar.

Kedua, lembaga pendidikan akan mencatat informasi anak untuk didaftarkan sebagai calon penerima KIP, yang akan diajukan ke Kemendikbud atau Kemenag.

Ketiga, Kementrian Pendidikan dan Kebudayaan (Kemendikbud) atau Kementrian Agama (KEMENAG) akan menerbitkan Surat Keputusan (SK) penerima KIP ke lembaga atau bank penyalur yang ditunjuk.

Keempat, dinas pendidikan/Kantor, Kemenag kabupaten atau kota akan mengirimkan surat pemberitahuan penerima KIP ke sekolah/madrasah/lembaga pendidikan lainnya.

Kelima, sekolah/madrasah/lembaga pendidikan lainnya akan menginformasikan kepada orang tua/peserta didik mengenai lokasi dan waktu pengambilan dana berdasarkan informasi dari Dinas Pendidikan. 
Keenam, peserta didik bersama orang tua dapat mengambil bantuan dana KIP ke lembaga/bank penyalur dengan membawa KIP dan salah satu bukti pendukung seperti surat keputusan atau identitas lainnya (KTP atau Kartu Pelajar).

\section{Pemanfaatan Program Indonesia Pintar}

Pemanfaatan menurut kamus besar Bahasa Indonesia, menyebutkan bahwa pemanfaatan berasal dari kata dasar guna, faedah (Nasional, 2008). Kemudian mendapat imbuan pe-an yang mengandung arti yaitu proses, cara dan perbuatan memanfaatkan sesuatu dalam hal ini pemanfaatan terhadap efektivitas penggunaan alokasi dana Bantuan Siswa Miskin (BSM) atau Program Indonesia Pintar (PIP) terhadap kegiatan pembiayaan dalam proses pembelajaran selama menempuh pembelajaran.

Pemanfaatan dana Program Indonesia Pintar (PIP) berdasarkan petunjuk teknis antara lain: (1) Pembelian alat tulis sekolah; (2) Pembelian pakaian dan perlengkapan sekolah (sepatu, tas, dll); (3) Transportasi siswa ke sekolah; (4) Uang saku siswa ke sekolah; (5) Biaya kursus/les yang tidak diselenggarakan pihak sekolah (Kemendikbud, 2015)

Dana Program Indonesia Pintar diterima langsung oleh pihak siswa atau orang tua, penerima wajib menggunakan dana dengan sebijak mungkin dan sesuai dengan ketentuan. Orang tua sebagai pemegang dana PIP diharapkan dapat mengelola semaksimal mungkin agar dapat berguna dengan baik dan bermanfaat untuk pemenuhan kebutuhan sekolah anak. Dengan demikian anak akan terjamin pendidikannya sampai ke jenjang yang lebih tinggi sesuai dengan program pemerintah wajib belajar 12 tahun.

\section{SIMPULAN DAN SARAN}

Dari uraian di atas dapat disimpulkan bahwa Program Indonesia Pintar (PIP) melalui Kartu Indonesia Pintar (KIP) dapat membantu meringankan biaya pendidikan bagi siswa yang kurang mampu. Program ini juga dimaksudkan untuk menekan angka putus sekolah dan mengembalikan siswa yang sudah tidak bersekolah kembali bersekolah seperti sebelummnya. PIP ini adalah penyempurnaan dari BSM (Bantuan Siswa Miskin), siswa tidak lagi mempunyai alasan untuk tidak sekolah karena masalah biaya karena biaya administrasi sudah ditanggung oleh BOS (Bantuan Operasional Siswa) dan untuk perlengkapan seperti alat tulis, seragam, sepatu dan tas dibantu dengan KIP tersebut.

KIP ini merupakan suatu bentuk dorongan untuk mempermudah program WAJAR 12 tahun (Program Belajar 12 Tahun) yang nantinya dapat membantu siswa dalam menempuh pendidikan sampai tingkat SMA/SMK sederajat. Bantuan tersebut tidak hanya dikhususkan untuk siswa namun juga untuk penyandang disabilitas, pondok pesantren dan Lembaga Pelatihan Kusus. Jadi, semua yang seharusnya sangat membutuhkan dapat dibantu dengan adanya KIP ini.

Untuk pemerintah agar dapat mendata masyarakat/siswa yang benar benar membutuhkan, dengan data yang terbaru dengan berbagai pertimbangan agar PIP ini dapat berguna dengan baik, untuk masyarakat juga dapat memperikan data yang akurat dengan sesuai keadaan ekonomi, agar masyarakat yang sangat membutuhkan dapat terbantu dan sejalan dengan program pemerintah. Dan juga untuk orang tua yang mendapat bantuan KIP ini dapat menggunakan dana dengan semestinya tidak digunakan untuk kepentingan pribadi, namun digunakan untuk memenuhi kebutuhan siswa.

\section{DAFTAR PUSTAKA}

Astuti, R. S. (2017). Implementasi Kebijakan Kartu Indonesia Pintar dalam Upaya Pemerataan Pendidikan Tahun Ajaran 2015/2016 di SMP N 1 Semin. Jurnal Kebijakan Pendidikan, VI(2), 21-27.

Djoyosuroto, R. S., Prasetyono, D. W., \& Mulyani, S. (2018). Implementasi Program Kartu Indonesia Pintar (KIP) di SMA Negeri 2 Dumoga. MAP (Jurnal Manajemen Dan Administrasi Publik), 1(1), 15-30.

Nasional, D. P. (2008). Kamus Bahasa Indonesia. Jakarta: Pusat Bahasa.

Nurmiati. (2017). Dampak Program Indonesia Pintar terhadap Siswa Miskin di SMA Negeri 1 Masalle Kabupaten Enrekang. Jurnal Sosialisasi Pendidikan Sosiologi- 
FIS UNM, 4(1), 60-65.

Retnaningsih, H. (2017). Program Indonesia Pintar: Implementasi Kebijakan Jaminan Sosial Bidang Pendidikan (Studi di Kota Kupang, Provinsi Nusa Tenggara Timur dan Kota Palembang, Provinsi Sumatera Selatan). Aspirasi, 8(2), 161-177.

Saraswati, L. N. (2017). Implementasi Kebijakan Program Indonesia Pintar (PIP) pada Jenjang Sekolah Dasar di Kecamatan Sungai Pinang Kota Samarinda. EJournal Administrasi Negara, 5(4), 6737-6749.
Suastha, R. D. (2016, August 16). Pengiriman Kartu Indonesia Pintar Mandeg di Kelurahan. CNN Indonesia. Retrieved from

https://www.cnnindonesia.com/nasional/2 0160816143211-20-151752/pengirimankartu-indonesia-pintar-mandeg-dikelurahan

Taufiqurokhman. (2014). Kebijakan Publik. Jakarta: Fakultas Ilmu Sosial dan Ilmu Politik Universitas Moestopo Beragama. 